\title{
The Heterogeneity of Tort Law
}

\author{
John Murphy*
}

\begin{abstract}
This article tests the plausibility of several leading, explanatory theories of tort by reference to the fact that tort law possesses neither the juridical nor the structural unity that the relevant theories ascribe to it. It considers a wide range of tort actions that reveal a much more heterogenous body of law than any of the targeted theorists admit exists. It concludes that, taken together, tort law's varying liability bases, its departures from the requirement of a rights infringement, its structural variations and its remedial diversity combine to belie the various reductionist claims the theorists in question make.
\end{abstract}

Keywords: Tort law; corrective justice theory; rights theory

\section{A Introduction}

Only stutteringly, over the course of more than a century, did jurists come to regard tort as a distinct legal category. As Milsom wrote:

Only at the end of the seventeenth century does our sense of tort begin to appear; and it was not a commonplace until much later ... In 1720 there was a book published called The Law of Actions on the Case ... [yet] [a]s late as 1873 Underhill still thought some explanation desirable: his title was Law of Torts, or Wrongs Independent of Contract. Pollock, in 1887 seems to have been the earliest to use Law of Torts [alone]'.

Pollock was the first to speak of 'the law of torts' without qualification. He made it his aim 'to show that there really is a Law of Torts, not merely a number of rules of law about various kinds of torts ... a true living branch of the Common Law, not a collection of heterogeneous instances'. But Pollock struggled to find a unifying thread; and the problem still persists. Some authors simply presume the existence of tort's juridical unity (by which I mean commonality among the constitutive rules ${ }^{3}$ ). Their textbooks promise an account of the law of tort (singular) while others (following Pollock) appear doubtful about such unity, adopting the law of torts (plural) as their title.

This article explores problems that arise for certain explanatory theories by virtue of the fact that, contrary to what they claim, none of the putatively unifying features they advert to really works. It suggests that, whatever other valuable insights they may offer, the reductionist ambitions of these explanatory theories are thwarted by this fact. In saying 'explanatory theories', I mean theories which purport explain tort law in its entirety: not just the various rules and doctrines, but also their rationales. They include interpretive theories which claim to supply 'the best account of the normative structure of the law as that law is found in the actual jurisdictions within which we live', for it is clear that the ultimate ambition of the interpretive theorist is an exercise in explanation. ${ }^{5}$ In saying 'reductionist theories', I mean theories presenting an account of tort law

\footnotetext{
* Lancaster University. Email j.murphy2@lancaster.ac.uk Thanks are owed to Sara Fovargue, James Goudkamp, Sarah Green, Jane Stapleton and the anonymous referees for their helpful comments on earlier versions.

${ }^{1}$ SFC Milsom, Historical Foundations of the Common Law (OUP, 1981) 295-300.

${ }^{2} \mathrm{~F}$ Pollock, The Law of Torts: A Treatise on the Principles of Obligations Arising from Civil Wrongs in the Common Law (Stevens \& Sons, 1887) vi.

${ }^{3}$ The putative juridical commonalities addressed here are (i) the liability bases of torts and (ii) the idea that all torts are characterised by the wrongful infringement of ex-ante private law rights.

4 A Beever, $A$ Theory of Tort Liability (Hart Publishing, 2016) 5 (emphasis added).

${ }^{5}$ For example, Beever, a leading advocate of such theorisation, concedes that an 'interpretive theory' seeks to 'provide ... a unified explanation of the law': A Beever, Rediscovering the Law of Negligence (Hart Publishing, 2007) 24.
} 
centred upon a single norm, principle or other organising feature which putatively underpins and renders intelligible the disparate array of tort actions.

Two broad classes of explanatory tort theory can be identified. ${ }^{6}$ They are corrective justice theories and rights theories. Many authors could be placed into these two camps, but for reasons of space, I address closely only the work of certain leading lights from both fields: ${ }^{7}$ that of Ernest Weinrib and Allan Beever, as corrective justice theorists; and that of Robert Stevens and John Goldberg and Benjamin Zipursky as rights theorists. ${ }^{8}$

At the heart of this article is the contention that, although each of these theorists makes clear their ambition to explain the whole of tort law as it presently stands, ${ }^{9}$ a significant explanatory hurdle exists for them all in the shape of tort law's heterogeneity. In particular, three aspects of this heterogeneity clash with core claims made in the theories considered. The first we may call juridical heterogeneity. The problem here is that tort's lack of juridical unity undermines the idea that the diverse members of the tort family can somehow be linked by reference to a common juridical feature. The second may be called structural heterogeneity. Here, it is the fact that torts are not uniformly structured that clashes with the theories in issue, for they all insist that torts are bilaterally structured according to a privity principle that is as central to tort law as it is to contract.

The third problematic feature of tort's heterogeneity concerns the absence of a primary remedy (ie, one that is always available, regardless of which tort is in play). The theoretical implications of tort's remedial heterogeneity are less obvious than those associated with its varying liability bases and structural variations. After all, there is nothing particularly suggestive about the fact that tort law provides an array of different remedies: many other branches of the law do likewise. ${ }^{10}$ The essential point is not, however, that tort law makes available an array of different remedies. Rather, it is that no single remedy constitutes the elusive unifying thread because no single remedy is universally available. The argument that there is such a remedy has most forcefully been made by John Gardner. ${ }^{11}$ He thinks that reparative damages are always available in tort, that they are tort's most distinctive characteristic and that they are key to its unity.

Though the explanatory theories with which I am principally concerned do not state explicitly that they consider tort law to be unified by reparative damages in the way that Gardner does, it is nonetheless clear that most of them think this way. ${ }^{12}$ Accordingly, if Gardner is right,

\footnotetext{
${ }^{6}$ Although some economic theories of tort law have explanatory ambitions, most are overtly normative in nature.

7 I leave to one side those economic theories that have principally explanatory aims: they are rather dated and have been convincingly discredited elsewhere. In terms of other contemporary explanatory theories, the single biggest omission is probably that of Arthur Ripstein. His work is undoubtedly important and arguably the clearest Kantian account of tort law on the market. However, his work is less well known than that of his colleague, Ernest Weinrib and by his own admission, his book, Private Wrongs (Harvard University Press, 2016), merely 'builds on Weinrib's arguments' (ibid, $\mathrm{x}$ ) and on the work of 'other writers who have contributed to rights-based accounts of tort law' (ibid, xi). Certainly, Ripstein's account is many respects similar to that of Allan Beever; yet it is much less assiduous in attempting to connect the theory to the extant law. For a penetrating engagement with, and critique of, Ripstein's book, see S Hershovitz, 'The Search for a Grand Theory of Tort Law' (2017) 130 Harv L Rev 942.

${ }^{8}$ While it is true that Goldberg and Zipursky would identify themselves as civil recourse theorists, it is clear that on the substance of tort law (as opposed to its mechanics) they adhere to the rights-based canon. See, eg, JCP Goldberg and BC Zipursky, 'Torts as Wrongs' (2010) 88 Texas L Rev 917.

${ }^{9}$ Weinrib makes clear that his aim is 'to understand what private law is' (EJ Weinrib, The Idea of Private Law (Harv UP, 1995) 8) as well as the rules that constitute the law (ibid, 147-152) the outcomes that they generate (ibid, 199) and the reasoning offered by judges (ibid, 219-221). Beever, too, is concerned with the idea that corrective justice theory 'provides far greater explanatory power than the current dominant models' (Beever (n 5) 39). Stevens by contrast claims that a 'rights-based model of the law of torts gives a better account of the common law as we find it' than rival conceptions (R Stevens, Torts and Rights (OUP, 2007) 306) (Elsewhere he describes his thesis in Torts and Rights as being 'primarily a descriptive one': R Stevens, 'The Divergence of the Australian and English Law of Torts' in S Degeling, J Edelman and J Goudkamp (eds), Torts in Commercial Law (Thomson Reuters, 2011) 40). Finally, Goldberg and Zipursky also proclaim the 'descriptive superiority' of their view of tort law (ibid, 920).

${ }^{10}$ For example, injunctions, specific performance and damages are all possible remedies under the law of contract.

11 J Gardner, 'Torts and Other Wrongs' (2012) 39 Florida State Univ L Rev 43 52-57.

${ }^{12}$ For details of the theorists who think this, and for the damaging effect, nothwithstanding, of tort's remedial heterogeneity for those that do not see section D.
} 
my target theorists will have ready-made a unifying feature of the kind that they make central to the success of their respective reductionist theories. If, however, Gardner's thesis is wrong, then tort's remedial heterogeneity will constitute a further source of explanatory difficulty.

I shall argue that reparative damages are not universally available as of right in tort. There are quite a few torts - as we shall see - in which the only available remedy cannot possibly be conceived in such terms. There are even some tort actions in which the only available remedy addresses neither measurable physical damage, ${ }^{13}$ nor the infringement of a right ${ }^{14}$ thus rendering any talk of reparation inapt.

In Section B, I expose the absence of a single organising juridical principle in tort law and explain why this is problematic for the theories in view. I contend, in particular, that variations in liability bases - from strict liability at one end, to torts requiring proof of malice ${ }^{15}$ or intention, ${ }^{16}$ at the other - are a major source of explanatory difficulty for corrective justice theorists. ${ }^{17}$ As against rights theorists, I advert to several important torts which cannot be explained in terms of the wrongful infringement of private law rights, thus undermining the overly-simplistic claims that ' $\mathrm{t}]$ he law of torts is concerned with the secondary obligations generated by the infringement of rights'; ${ }^{18}$ and that ' $\left.\mathrm{t}\right]$ he infringement of rights ... is the gist of the law of torts'. ${ }^{19}$ In Section $\mathrm{C}, \mathrm{I}$ attend to tort's structural heterogeneity, pointing out numerous deviations from the putative norm of relational - $i e$, bilateral - wrongdoing. ${ }^{20}$ The deviations I consider have important ramifications for all of my target theorists because, although they use different terminology, they all commit themselves to the same basic idea that tort's bilateralism is a structural imperative: that is, torts centre upon the right-duty relation which 'connects two, and only two, persons'. ${ }^{21}$ In Section D, I show to be misguided the idea that there exists a universally available remedy around which tort law's unity may be constructed. In Section E, I offer a series of concluding remarks, drawing together the implications of tort's heterogeneity for these theories.

\section{B Juridical Heterogeneity}

Certain corrective justice theorists - most notably, Weinrib - reject the possibility of strict liability in tort. ${ }^{22}$ At the same time, some rights theorists insist that torts necessarily involve the

\footnotetext{
13 The absence of a reparative award is acutely problematic for corrective justice theories since they place front and centre the idea that tort law serves to correct (or reverse) wrongs that have been committed.

${ }^{14}$ The inability to view the only available remedy as a response to a rights violation is obviously problematic for rights theorists who anchor their conception of damages to such violations: see, eg, R Stevens, Torts and Rights (OUP, 2007)5991.

${ }^{15}$ Examples include malicious prosecution, misfeasance in a public office, lawful means conspiracy and abuse of process. See P Cane, 'Mens Rea in Tort Law' (2000) 20 OJLS 533.

${ }^{16}$ The meaning of intention varies in tort. In the tort of causing loss by unlawful means 'there must be an intention to cause loss' (OBG Ltd v Allan [2008] 1 AC 1, [62] (Lord Hoffmann)), whereas in the context of trespass to land, D need only have taken the relevant steps intentionally. He need not intend harm, and will be liable if he strayed onto C's land without consent and by mistake (however reasonable that mistake may have been): Basely v Clarkson (1682) 3 Lev 37.

${ }^{17}$ It is an oversimplification to imagine a neat spectrum capturing different degrees of fault in tort: see JCP Goldberg, 'Ten Half-Truths about Tort Law' (2008) 42 Valparaiso Univ LR 1221. But my basic point - that liability bases can vary considerably (even if not very neatly) - remains true.

18 Stevens (n 14) 2.

19 ibid.

20 Relational/bilateral wrongdoing is wrongdoing which links two and only two parties.

${ }^{21}$ Weinrib (n 9) 64. For some, it is this purely bilateral structure which grounds the claim that tort law is about corrective justice; about A making direct reparation to B after B has wrongly disturbed the equilibrium between them via the commission of a tort. For others, this structural claim is central to the idea that tort is best explained in terms of a series of ex-ante rights that tort victims hold directly against tortfeasors.

${ }^{22}$ As Weinrib puts it: 'the theoretical case for basing tort liability on the causation of harm without fault is inconsistent with the equality and correlativity of corrective justice and with the concept of agency of Kantian right': Weinrib (n 9) 203.
} 
infringement of primary rights such that, in definitional terms, a 'tort is a species of wrong ... [involving] a breach of a duty owed to someone else'. ${ }^{23}$ Here I demonstrate that neither school of thought accurately captures the true position.

\section{$1 \quad$ Strict Liability in Tort}

Medieval tort law comprised little more than a cluster of rules governing trespasses to land, the person and chattels. Accordingly, as Milsom wrote, '[h] ad some lawyer in the late $14^{\text {th }}$ Century undertaken to write a book about what we should call tort law, about actions brought by the victims of wrongs, he would have called his book "Trespass". ${ }^{24}$ That self-same jurist would almost certainly also have identified strict liability as one of tort's defining features. ${ }^{25}$ So, if anyone had then proffered an explanatory theory of tort, she, too, would probably have emphasised the strictness of tortious liability. Nowadays, however, with negligence very much in the ascendancy - and notwithstanding one valiant attempt to do $\mathrm{so}^{26}-$ it would seem odd to place anything other than fault-based liability to the fore when explaining tortious liability. ${ }^{27}$

That said, strict liability torts are by no means extinct. Private nuisance, conversion, passing off and the various statutory intellectual property torts are all good examples of its continuing vitality. Most important of all, vicarious liability ensures a significant strict liability overlay in relation to all torts, including those based on fault.

The significant continuing presence of strict liability in tort presents an especial problem for Weinrib's theory. ${ }^{28}$ For, 'whereas corrective justice treats the litigants as equals, strict liability ... [is concerned with] only one of the parties' so that, without any enquiry into whether the defendant was at fault, 'the interests of the plaintiff unilaterally determine the contours of what is supposed to be a relationship of equals. ${ }^{29}$ Acknowledging that strict liability in tort would represent a shortcoming in his theory, Weinrib devotes an entire chapter of The Idea of Private Law to showing that well-known instances of it are, properly understood, not genuine examples of strict liability at all. ${ }^{30}$ In particular, he offers imaginative re-interpretations of private nuisance, the rule in Rylands $v$ Fletcher and vicarious liability, endeavouring to show that each is better understood in terms of the fault principle.

Admittedly, it has always been a tricky question whether private nuisance involves strict liability. But things are much clearer in relation to both Rylands and vicarious liability. They are

\footnotetext{
${ }^{23}$ Stevens (n 14) 2. Essentially the same point is made in Goldberg and Zipursky (n 8) 937.

${ }^{24}$ Milsom (n 1) 305.

${ }^{25}$ For an account of medieval tort law's concentration on strict liability, see D Ibbetson, $A$ Historical Introduction to the Law of Obligations (OUP, 1999) 58-62.

${ }^{26}$ Richard Epstein stands out as having mounted the most sustained effort to elaborate a strict liability basis of tort law. See RA Epstein, 'A Theory of Strict Liability' (1973) 2 Journal of Legal Studies 151, 'Defenses and Subsequent Pleas in a System of Strict Liability' and 'Causation - In Context: an Afterword' (1987) 63 Chicago-Kent LR 653. Cf SR Perry, 'The Impossibility of General Strict Liability' (1988) 1 Canadian Journal of Law and Jurisprudence 147.

${ }^{27}$ It is difficult to pinpoint an exact point in time at which the fault principle gained the ascendancy: see Ibbetson (n 25) 158; T Weir, 'The Staggering March of Negligence' in P Cane and J Stapleton (eds), The Law of Obligations: Essays in Celebration of John Fleming (OUP, 1998) 97.

${ }^{28}$ Strict liability under the rule in Rylands v Fletcher (or its American counterpart, dealing with abnormally dangerous activities) is also a problem for rights theorists. Sometimes they admit this: see, eg, the concession by Goldberg and Zipursky that 'our insistence that tort law is a law of wrongs puts us in a difficult spot when it comes to explaining the presence of common law strict liability for abnormally dangerous activities... [since liability attaches] to activities that are not wrongful': JCP Golberg and BC Zipursky, Torts (OUP, 2010) 267. For detailed analysis of the inability of their theory to account for this tort, see GC Keating, 'Strict Liability Wrongs' in J Oberdiek (ed), Philosophical Foundations of the Law of Torts (OUP, 2014) 294-5.

${ }^{29}$ Weinrib (n 9), 177.

30 ibid, ch 7 .
} 
both rightly considered to be classic illustrations of strict liability. So far as Rylands is concerned, courts at the highest level have put beyond doubt the fact that such liability is strict. ${ }^{31}$

As regards vicarious liability, things are equally clear. In one mid- $20^{\text {th }}$ century case, Lord Reid explained that, in such cases, 'an employer, though guilty of no fault himself, is liable for the damage done by the fault or negligence of [another]. ${ }^{32}$ In other words, the relevant tort is committed by the employee, not the employer. This understanding of vicarious liability was wholeheartedly endorsed by the House of Lords some fifty years later in the Majrowski case. ${ }^{33}$ There, the 'master's tort' understanding of the principle (on which Weinrib centres his fault-based conception) was conclusively quashed. It is now therefore impossible - at least if one takes seriously what has been laid down by the senior courts $^{34}$ - to distil a plausible fault-based understanding of vicarious liability from the leading cases. ${ }^{35}$

Of course, it is still possible to argue that vicarious liability would be better conceived in terms of the master's tort. But such arguments are not are open to Weinrib who commits himself to supplying an explanatory (not prescriptive) theory of tort. ${ }^{36}$ Nor do Weinrib's difficulties end there. He admits that any instance of strict liability would be inexplicable according to his theory given that, in his view, corrective justice and strict liability are completely irreconcilable. ${ }^{37}$ So, regardless of what our most senior judges have said about Rylands and vicarious liability, Weinrib is inescapably on the back foot when it comes to explaining other significant strict liability torts on which he is entirely silent.

The qualifier 'significant' is important here, since although it may be too much to expect Weinrib to reconcile every single strict liability tort with his theory - especially in a work purportedly about all of private law - it is clear that mere silence is not enough in respect of important strict liability torts. Put otherwise, although it may be excusable to stay silent on a tort like passing off which has been significantly eclipsed by a system of registered trademarks, the same cannot be said of mainstream torts like conversion and trespass. When an entire data set $\mathrm{SL}_{1}-\mathrm{SL}_{6}$ (these being various instances of strict liability) appears to present a problem of fit for one's explanatory theory, it is no defence of that theory to show merely (as Weinrib doesseeks to do) that $\mathrm{SL}_{1}, \mathrm{SL}_{2}$ and $\mathrm{SL}_{3}$ might be erroneous inclusions in that data set. So long as $\mathrm{SL}_{4}-\mathrm{SL}_{6}$ are independently important, then silence in relation to them is highly suggestive. Without suggesting that Rylands is unimportant, it is nonetheless true that cases involving that tort are nowadays rare. (Until the House of Lords decided the Cambridge $W$ ater case ${ }^{38}$ in the late $20^{\text {th }}$ Century, it might plausibly have been argued that the rule had lapsed into desuetude.) So if Weinrib felt forced to select certain torts for discussion, his choice of Rylands over, say, conversion or trespass seems odd. ${ }^{39}$

\footnotetext{
${ }^{31}$ Cambridge Water Co Ltd v Eastern Counties Leather plc [1994] 2 AC 264; Transco plc v Stockport MBC [2004] 2 AC 1. Cf the recent doubts about the strictness of liability in Rylands in Ripstein (n 7) 127-130.

32 Stavely Iron \& Chemical Co v Jones Ltd [1956] App Cas 627, 643 (Lord Reid).

${ }^{3}$ Majrowski v Guy's \& St Thomas' NHS Trust [2006] 3 WLR 125. See also Armes v Nottinghamshire CC [2017] UKSC 60, [91].

34 For the argument that serious reflexive scholarship must do this, see J Stapleton, 'Taking the Judges Seriously' https://ox.cloud.panopto.eu/Panopto/Pages/Viewer.aspx?id=c43ce0fc-7623-47ec-a1e8-a8cf0099a581.

35 The fact that Majrowski makes implausible a 'master's tort' conception of vicarious liability gives rise to a second problem for all my target theorists. It is that it countervails against the bilateralism/privity principle to which they all subscribe: see section $\mathrm{C}$ part 4 , below.

${ }^{36}$ If a theorist feels forced to argue that a rule of law (or a broadly held, existing understanding of that rule) ought to change in order for the rule in question to fit their theory, then far from salvaging their theory from the problem of fit presented by the rule, the theorist's recourse to prescriptive writing - ie, suggesting that the law (or and understanding of it) must change in such and such a way -is an admission of the failure of their the theory to do what it was set up to do, namely, explain the law as we find it. Put bluntly, explanatory theorists set themselves the task of supplying a theory that fits the law, rather than the task of identifying ways in which the law must be amended so that it conforms to their theory. Lapses, into prescription play no part in securing the ultimate ambition.

37 Weinrib (n 9) 171.

${ }^{38}$ Cambridge Water Co Ltd v Eastern Counties Leather plc [1994] 2 AC 264.

${ }^{39}$ Conversion and trespass both have far greater present-day significance than Rylands.
} 
Just because Weinrib cannot satisfactorily account for tortious strict liability does not warrant the conclusion that all corrective justice theories fail on this front. Allan Beever, for example, has no especial hostility towards strict liability torts so long as strict liability is understood in the purely formal sense that proof of fault is not an ingredient of the specific tort. ${ }^{40}$ His view is unassailable. Yet it is also banal. What he says is only correct because of the definition of strict liability that he adopts. There are several torts that do not contain a specific fault requirement (the equivalent, that is, of the breach of duty element in negligence). But for two reasons this does not secure Beever's position. First, because the conception of strict liability upon which he relies is highly idiosyncratic with few, if any other, adherents. ${ }^{41}$ And secondly because, once one considers torts that meet the usual definition of strict liability - ie, liability regardless of legal fault - Beever's account can be seen to fail in its explanatory ambitions given that such torts clash with his insistence that corrective justice requires defendant and claimant to be treated as equals. ${ }^{42}$

\section{Torts not Requiring Rights Infringements}

Tort's juridical heterogeneity also poses explanatory problems for rights theorists because it undermines their central claim that the unity of torts inheres in the fact that they all involve the infringement of ex-ante private law rights held by the claimant directly against the defendant. Goldberg and Zipursky, for example, regard 'the idea of civil recourse and the ideas of relational, legal, injury-inclusive wrongs as unifying features of tort law and tort theory'. ${ }^{43}$ Yet, numerous wellestablished tortious causes of action do not fit this description.

\section{(a) The Rule in Rylands $v$ Fletcher}

One very well-known cause of action that contradicts the rights-based conception of tort law is the rule in Rylands $v$ Fletcher. It clashes because, in juridical terms, the claimant is afforded a cause of action without having to show that any ex-ante private law right of his has been violated by the defendant. As Jaffey puts it: '[a] claim under the rule in Rylands v Fletcher ... arises from a primary liability relation that allocates to $\mathrm{D}$ the risk of loss to $[\mathrm{C}]$ without imposing on him a duty to prevent it'. ${ }^{44}$ Recognising this, Goldberg and Zipursky write:

Doctrinally, the sharpest challenge to a wrongs-based theory of torts is found in decisions such as Rylands $v$ Fletcher and the doctrine of strict liability for harms caused by abnormally dangerous activities. These forms of liability, after all, explicitly disavow having anything to do with wrongs. Liability is imposed even though the defendant has caused harm through conduct that the courts themselves are at pains to say is entirely permissible... It is possible that these are true exceptions to the otherwise wrongs-based nature of tort law. ${ }^{45}$

Of course, as against the understanding expressed by these authors, one possible reply would be to say that $\mathrm{C}$ does in fact have a right that $\mathrm{D}$ not damage his land by causing a dangerous object to be unleashed on it. On this view, Rylands cases appear orthodox from the perspective of rights theory. However, no such understanding is tenable. For while D is undoubtedly under a duty to manage carefully things that are on his land, he is under no duty to prevent their escape through

\footnotetext{
${ }^{40}$ Beever offers three possible interpretations of strict liability: (i) liability based on causation alone; (ii) liability arising regardless of fault and (iii) liability in torts that do not specifically require proof of fault (eg, trespass). He adopts the third of these; strict liability in the formal sense: Beever (n 4) 33.

${ }^{41}$ Beever points to just one textbook as holding a similar view, namely, WE Peel and J Goudkamp, Winfield and Jolowicz. on Tort (Sweet and Maxwell, 2013).

${ }^{42}$ Liability imposed purely by reference to the interests of $\mathrm{D}$ and which ignores those of $\mathrm{C}$ is incompatible with corrective justice since, Beever argues, 'justice ... requires a standard for judging the behaviour of the defendant that treats the claimant and the defendant as equals': Beever (n 5) 83.

${ }^{43}$ Goldberg and Zipursky (n 8) 978.

44 Peter Jaffey, 'Liabilities in Private Law' (2008) 14 Legal Theory 233, 240.

45 Goldberg and Zipursky (n 8) 951.
} 
causes that have nothing whatever to do with his management of them. ${ }^{46}$ The escape in Rylands itself had nothing whatever to do with what $\mathrm{D}$ did, or failed to do, in managing the reservoir. It was caused by work done by independent contractors before the accumulation occurred. The escape, in other words, was attributable to something other than a breach of any relevant duty on D's part.

Another possible objection to this 'no breach of a relevant ex-ante duty' interpretation of Rylands is the judicially promulgated suggestion that the rule is now a mere subset of the law of private nuisance. ${ }^{47}$ Naturally, the value for rights theorists of treating Rylands as part of private nuisance is that the latter can readily be understood in terms of rights infringements. However, they seem to reject this approach. Stevens acknowledges the judicial re-packaging of Rylands that has occurred, yet declines to adopt it. He prefers, instead, to attempt to insulate his theory from the challenge posed by Rylands by describing the rule as anomalous. ${ }^{48}$ Goldberg and Zipursky also implicitly reject the private nuisance escape route because they see the rule in Rylands as a 'sui generis cause of action'. ${ }^{49}$ They regard it as a trivial exception to their theory, as some kind of outlier: a 'genre of case that sits at the margin of tort law'..$^{50}$

Unfortunately, it is not entirely clear what these authors mean when they describe the rule in Rylands as an 'anomaly' or 'sui generis cause of action'. If by anomaly what Stevens means is that the rule ought never to have been created, then he is resorting to a nakedly prescriptive claim in order to spare his blushes. Yet such claims have no rightful place in his avowedly explanatory theory of tort law. They amount to saying that the law should be changed in order to fit his theory. Yet a theory that is genuinely explanatory must account for the law as it presents itself; and Stevens purports to do just that. ${ }^{51}$

Equally, Goldberg and Zipursky's strategy - of describing the rule in Rylands as a 'sui generis cause of action' which exists at the outer edges of tort law - fares no better. Even if Rylands sits at the margins, this in no way changes the fact that it is part of tort law. The island of Bornholm is Danish. It lies off the south east tip of Sweden and is much closer to Sweden than it is to Denmark. It has obvious linguistic and cultural affinities with Sweden, and yet it is firmly Danish in every important juridical sense. ${ }^{52}$ Its being an outlier does not, however, undermine its juridical status.

In any case, depicting Rylands as a sui generis cause of action is also wrongheaded insofar as weight is paced on Rylands actions not requiring the breach of an ex-ante, private law duty. There is, as the following paragraphs illustrate, nothing unique (as sui generis suggests) about this. Other tort actions equally eschew the need for such a breach.

\section{(b) Other Tort Actions not Requiring Breach of the Claimant's Rights}

Quite a number of tort actions can be brought without the need to show that the defendant acted in breach of an ex-ante private law duty. These include the tort of causing loss by unlawful means, the dependency action under the Fatal Accidents Act 1976, the action for inducing breach of contract, the action created by the Congenital Disabilities (Civil Liability) Act 1976, and the tort of public nuisance.

\footnotetext{
46 This observation belongs to NJ McBride and R Bagshaw, Tort Law (6 ${ }^{\text {th }}$ ed, Pearson, 2018) 445

47 There is considerable scope for such an interpretation: see, eg, Cambridge Water Co Ltd v Eastern Counties Leather plc [1994] 2 AC 264, 304 (Lord Goff): 'the rule in Rylands v Fletcher was essentially concerned with an extension of the law of nuisance to cases of isolated escape'; Transco plc v Stockport MBC [2004] 2 AC 1, [9], [52] and [92].

${ }^{48}$ Stevens (n 14) 299. It is not clear why he does not accept the 'Rylands as part of private nuisance' approach, but it seems reasonable to speculate that, like others, he doubts its soundness. For such doubts, see D Nolan, 'The Distinctiveness of Rylands v Fletcher' (2005) 121 LQR 421; J Murphy, 'The Merits of Rylands v Fletcher' (2004) 24 OJLS 643.

49 Goldberg and Zipursky (n 8) 952.

50 ibid, 952.

${ }^{51}$ See, eg, Stevens (n 14) 74, 306.

${ }^{52}$ A similar story could be told about Strasbourg. Regardless of geographical propinquity to Germany and the mongrel linguistic and cultural traditions found there, the city is today as indisputably French as Bornholm is Danish.
} 


\section{(i) The Unlawful Means Tort and the Dependency Action}

Stevens rightly acknowledges that both the unlawful means tort and the dependency action under the Fatal Accidents Act are incompatible with his rights-based theory. ${ }^{53}$ The former clashes because a claimant holds neither a right to trade, nor a right to economic welfare that is good against the defendant. Breach of an ex-ante right is therefore not an ingredient of this tort. The dependency action also amounts to a tort claim brought in the absence of an ex-ante right held by the claimant directly against the defendant. Dependency actions are parasitic upon the infringement by the defendant of a right held by the deceased against the defendant, and not one held by the claimant. ${ }^{54}$

Conscious of their incompatibility with his theory, Stevens attempts to circumvent the explanatory hurdles he faces. He suggests various reasons to tolerate the results that are produced by these actions even though they contradict a central pillar of his theory. He argues that the unlawful means tort can be justified because it prevents defendants from using third parties as a means to their own ends. ${ }^{55}$ And he contends that the dependency action has going for it the fact that it produces an outcome that is a closer approximation to the wrong not having been committed than would be achieved if the only available claim lay with the estate. ${ }^{56}$ But neither of these points rescues him because they are points that have nothing to do with the claimant's rights. They are distractions which, at most, show that the unlawful means tort and the dependency action are in some sense palatable even though they contradict his theory. But palatable or not, they countervail against his insistence that tort law 'is concerned with the secondary obligations generated by the infringement of primary rights, ${ }^{57}$

Goldberg and Zipursky do not address the unlawful means tort head on. In one article, they note in passing the existence of something akin to this tort mentioned in the Restatement (Third) of Unfair Competition (1993) \1(a) $;{ }^{58}$ but they offer no comment on its compatibility with their theory. ${ }^{59}$ Nor do they address the much closer comparator, the (American) tort of interference with business relations, which covers the classic case of intimidatory threats made by $\mathrm{D}$ to a third party, $\mathrm{T}$, so as to cause $\mathrm{T}$ to act in a way that causes financial loss to $\mathrm{C} .{ }^{60} \mathrm{It}$ is clear, however, that this tort does not fit their conception of torts as relational wrongs. The duty-based wrong present in this tort is the one committed by $\mathrm{D}$ against $\mathrm{T}$ (through whom a mere loss - but no rights infringement - is visited upon $\mathrm{C}$ ).

\section{(ii) Inducing Breach of Contract}

Stevens' attempt to fend off the challenge posed by the action for inducing breach of contract is similarly unsuccessful. Here, the relevant breach is that of a contractual duty owed by an intermediary to the claimant. The defendant is held liable for inducing this breach, but does not breach an independent duty directly owed by him to the claimant.

Stevens suggests that, properly understood, the defendant is liable for breach of a putative 'accessory right' which is 'good against everyone else that they do not induce the infringement of the contractual right[s] we hold'. ${ }^{61}$ It is an ingenious interpretation of the action minted in Lumley

\footnotetext{
${ }^{53}$ Stevens (n 14) 188-190 and 174 respectively.

${ }^{54}$ See J Goudkamp and J Murphy, 'Tort Statutes and Tort Theories' (2015) 131 LQR 133.

55 Stevens (n 14) 188.

56 ibid, 176.

57 ibid, 2. These are typically obligations 'to make good the claimant's consequential loss or give up his own consequential gains': ibid, 59.

58 Goldberg and Zipursky (n 8) 940.

${ }^{59}$ The nearest that they get is when they explain why C cannot sue in fraud where A defrauds B in such a way as to produce economic loss to C: see JCP Goldberg, AJ Sebok and BC Zipursky, 'The Place of Reliance in Fraud' (2006) 48 Ariz LR 1001. But the compatibility of fraud with their theory is not in issue.

${ }^{60}$ See AB Long, 'Tortious Interference with Business Relations: “The Other White Meat” of Employment Law' (2000) 84 Minn LR 863 (and the cases cited therein at 874-5).

${ }^{61}$ Goldberg and Zipursky (n 8) 281.
} 
$v$ Gye. ${ }^{62}$ But it is nonetheless one that is contradicted by the leading case of OBG Ltd $v$ Allan ${ }^{63}$ in which their Lordships repeatedly said that Lumley instantiated a principle of accessory liability. Lord Hoffmann was crystal clear in distinguishing between the unlawful means tort and the action for inducing breach of contract. He said: ' $[\mathrm{t}]$ he tort of causing loss by unlawful means differs from the Lumley $v$ Gye principle [since] ... the unlawful means tort is a tort of primary liability... while Lumley $v$ Gye created accessory liability. ${ }^{64}$ Lord Nicholls and Lord Brown were of similar mind. ${ }^{65}$ Thus, much as Stevens might like there to be one, there is simply no relevant right held directly by the claimant against the defendant in a case of this kind. The action is inexplicable on Stevens' rightsbased model given his commitment to explaining the law as we find it. And this, I think, we must do; for if it were left to rights theorists to say which rights we do and don't have, their theories could never be falsified. Wherever one were needed, a right could simply be formulated or modified in order to make the cases fit the theory. ${ }^{66}$

Goldberg and Zipursky fare no better on this front. They acknowledge that there is tortious liability under Lumley, yet mischaracterise it as one of a number of 'common law torts that protect the interest in freely entering into transactions ${ }^{97}{ }^{67}$ But this must be wrong. The relevant right in such cases is an extant contractual right held by the claimant against a third party. It is not, as they suggest, a right against all the World that we be free to enter into transactions in the future. Our interest in protecting existing contracts, and our interest in being free to make other such contracts in the future, are very different beasts. The Lumley tort has nothing to do with future contracts.

Of the Kantians, only Beever devotes serious attention to the Lumley tort. He confesses to being unable to explain it and suggests that the action is a mistake. ${ }^{68}$ But this merely amounts to the prescriptive claim that the law should be changed in order to come into line with his theory. It is a deviation from his explanatory commitment.

\section{(iii) Public Nuisance and the Action under the Congenital Disabilities Act}

Actions for public nuisance ${ }^{69}$ as well as those brought under the Congenital Disabilities (Civil Liability) Act 1976 are equally inexplicable for rights theorists. With public nuisance, there is a frank concession by Stevens that many of the relevant cases are incompatible with his theory. ${ }^{70}$ One particular problem is that public nuisances involve the breach of public duties which correlate to a public rights. Stevens, however, insists that tort law concerns the infringement of private rights. ${ }^{71}$ Goldberg and Zipursky are similarly ensnared since they, too, maintain that there is something 'distinctively "private" about tort' such that 'we [must] conceive of torts as private wrongs' ${ }^{72}$

Whereas Stevens concedes the incompatibility, and contents himself with saying that ' $[\mathrm{i}] \mathrm{t}$ may be argued that public nuisance is sui generis, ${ }^{73}$ Goldberg and Zipursky imply (but do not state outright) that public nuisances are part of public law and need not, therefore, be explained by their

\footnotetext{
62 (1853) El \& Bl 216.

63 [2008] 1 AC 1.

64 ibid [8].

${ }^{65}$ Lord Hoffmann was clear that inducing breach of contract 'is a form of accessory liability', while Lord Brown spoke of the 'accessory liability which arises under the principle in Lumley $v$ Gye': ibid, [172] and [320] respectively.

${ }^{66} \mathrm{I}$ am grateful to Sarah Green for alerting me to these points.

${ }^{67}$ Goldberg and Zipursky (n 8) 940 (emphasis added).

${ }^{68}$ Beever (n 4) 146-154.

${ }^{69}$ Although principally a crime, the courts have made clear that an action in tort can be brought for public nuisance in certain circumstances: see In re Corby Group Litigation [2009] QB 335, [20] and [29]-[30] (Dyson LJ). And for discussion, see J Murphy, The Law of Nuisance (Oxford: OUP, 2010) 137-152.

${ }^{70}$ Stevens (n 14) 186-189.

71 ibid, 284: he is adamant that ' $[\mathrm{t}$ ]

${ }^{72}$ Goldberg and Zipursky (n 8) 919.

73 Stevens (n 14) 188.
} 
theory. ${ }^{74}$ Now, while it is true that injunctive relief secured by the Attorney General via the relator action (the English equivalent of the 'executive-branch action' of which they speak) is one possible remedy in such cases, it is equally true that public nuisances also sometimes make compensatory damages available. ${ }^{75}$ Such damages fit perfectly their civil recourse model according to which, they say, a tort will 'generate for its victim a private right of action ... against the wrongdoer' ${ }^{76}$ So public nuisance cannot straightforwardly be parcelled off as belonging exclusively to public law.

Perhaps predictably, as the sole UK-based lawyer among them, only Stevens addresses the Congenital Disabilities Act. He acknowledges the incompatibility of the action with his theory noting that it is granted in favour of a child born with disabilities who held no ex-ante right against the defendant. ${ }^{77}$ The action is parasitic upon a wrong committed against the child's mother. In an attempt to render the action more palatable, Stevens discusses the peculiar history of the Act. But doing so does not save his theory. The relevant action simply cannot be cashed out in terms of the infringement of ex-ante rights held by the claimant, and the contradiction of his theory remains.

Even if Stevens were to treat the rule in Rylands $v$ Fletcher as part of the law of private nuisance, there remains a sizeable number of tort actions that his theory cannot explain in terms of the infringement of claimants' ex-ante private law rights. Equally, even if Goldberg and Zipursky are spared the task of explaining various statutory actions considered here (because they are English statutes ${ }^{78}$ ), there remains a significant number of common law torts that they cannot explain including breach of contract, causing loss by unlawful means, ${ }^{79}$ public nuisance and the rule concerning abnormally dangerous activities.

\section{Structural Heterogeneity}

This section of the article considers another aspect of tort law's heterogeneity which has important implications for the theories in view: the fact that torts are not (despite the various theorists' claims to the contrary), always and necessarily, bilaterally structured. ${ }^{80}$

Although there is some variation in the terminology used, all of my target theorists make this structural claim. ${ }^{81}$ Indeed, it is no exaggeration to say that they all regard tort's bilateralism as

\footnotetext{
74 The implication inheres in the claims that tort 'does not vindicate public or communal interests' and that public nuisances 'are not wrongs to anyone in particular ... [but wrongs which] are appropriately addressed through executive-branch action': Goldberg and Zipursky (n 8) 937, 938.

75 In re Corby Group Litigation [2009] QB 335.

76 ibid, 918.

${ }_{77}$ Stevens (n 14) 185: 'the plaintiff had no legal personality and consequently no rights at the time of the tort'.

${ }^{78} \mathrm{It}$ is no answer to a challenge based on statutory torts to advert to the mere fact that a tort has statutory foundations. Most fundamentally, this is because so doing relies upon an untenable divide between statute and common law (see A Burrows, 'The Relationship Between Common Law and Statute in the Law of Obligations' (2012) 128 LQR 232, 234). For further reasons why tort theorists ought to be able to account for statutory torts, see J Murphy, 'Contemporary Tort Theory and Tort Law's Evolution' (2019) 32 Canadian Journal of Law and Jurisprudence (forthcoming).

79 The closest American counterpart to this tort is set out the Restatement (Second) of Torts (1977) SS 766-7. The action described there feeds off the prima facie tort doctrine that operates in the USA and is thus in conflict with Allen $v$ Flood [1898] AC 1. For whereas the former holds that any intentionally inflicted harm is recoverable unless justified, Lord Herschell made clear Allen (at 124) that 'an act prima facie lawful is not unlawful and actionable on account of the motive which dictated it'.

${ }^{80}$ For the interesting suggestion that, in fact, ' $[\mathrm{t}]$ ort obligations are at root omnilateral - they are owed by everyone and to everyone else' see GC Keating, 'The Priority of Respect Over Repair' (2012) 18 Legal Theory 293, 322.

${ }^{81}$ Goldberg and Zipursky speak in terms of 'relational wrongs': JCP Goldberg and BC Zipursky (n 8) 960; BC Zipursky, 'Rights, Wrongs, and Recourse in the Law of Torts' (1998) 51 V and L Rev 1, 59. Stevens and Beever prefer to talk in terms of the 'privity of torts': see Stevens (n 14) ch 8 and Beever (n 4) 117. Weinrib, by contrast, opts for
} 
a structural imperative. The core claim is that tort actions link two, and only two, parties: claimant and defendant.

Goldberg and Zipursky's commitment to the structural imperative is clear from their treatment of Palsgraf $v$ Long Island Railroad Co. ${ }^{82}$ Invoking Cardozo CJ's words in that case, they say: 'a tort plaintiff "sues in her own right for a wrong personal to her, and not as the vicarious beneficiary of a breach of duty to another." ${ }^{\prime 3}$ By contrast with the wrongs of criminal law - which they describe as "wrongs to the world or the state ${ }^{84}$ - they maintain that ' $\mathrm{t}$ ] orts are violations of legal directives with a different analytic structure. We call these relational directives. They are of the form: For all $x$ and for all $y, x$ shall not do $A$ to $y{ }^{85}$ Put otherwise, torts are 'personal to' the claimant in the sense that there was breach of a duty owed directly by defendant $X$ to claimant $Y$ (or a class of persons to which $\mathrm{Y}$ belongs). It is not enough, they say, that $\mathrm{X}$ has merely acted wrongfully in some basic (moral) sense. Rather, there must be breach of a legal duty owed to Y. This, they declare, is tort's 'substantive standing requirement'.

Also invoking the language of standing, Stevens insists that ' $[t]$ he only person who can enforce a right is the right-holder, and persons who suffer loss because of the infringement of someone else's right do not have standing to sue'. ${ }^{87}$ And corrective justice theorists are just as overtly committed to the structural imperative. There is scarcely a page of chapter 3 of The Idea of Private Law which does not mention Weinrib's view that corrective justice operates purely within bipolar relationships, ${ }^{88}$ while Beever, too, maintains that in tort there is a 'privity rule [according to which] ... a defendant can be liable to a plaintiff only if the defendant violated the plaintiff's rights' ${ }^{89}$

The centrality of the structural imperative within each of these theories cannot be overestimated. Each of the relevant theorists emphasises its significance with either remarkable depth of conviction or regularity (or both). ${ }^{90}$ Yet despite this, it is possible to identify a considerable amount of tort law that does not fit the pattern. The exceptions that exist - if exceptions they be - cannot be dismissed lightly. They are not mere anomalies, but instead, principles which have become firmly embedded in tort law, not just by virtue of their vintage, but also because of their repeated subsequent usage or because they stem from decisions made by our most senior courts. ${ }^{91}$

the term 'bipolarity': see, eg, EJ Weinrib, 'Deterrence and Corrective Justice' (2002-3) 50 UCLA Law Rev 621, 623 ('so far as corrective justice is concerned, the norms of tort law - and indeed of private law more generally reflect... the bipolar structure of private law').

82162 NE 99, 100 (NY 1928).

${ }^{83}$ Goldberg and Zipursky (n 8) 958. They go on to claim that in tort, 'rights of action are generated only in those who have been wronged': ibid, 960 .

84 ibid, 945.

85 ibid.

${ }^{86}$ BC Zipursky, 'Civil Recourse, Not Corrective Justice' (2003) 91 Georgetown LJ 695, 716; Goldberg and Zipursky (n 8) 957.

${ }^{87}$ Stevens (n 14) 173. Cf White v Jones [1995] 2 AC 207: this case grants a tort claim to someone other than the relevant right holder, and Stevens - recognising the clash with his theory - accepts that ' $[\mathrm{o}] \mathrm{n}$ a rights based model, White $v$ Jones appears anomalous': ibid, 178.

88 In a subsequent chapter, he goes on to assert that 'corrective justice necessarily connects two parties, no more and no less': Weinrib (n 9) 175.

${ }^{89}$ Beever (n 4) 117. For a full account of why he holds this view: see A Beever, 'Transferred Malice in Tort Law?' (2009) 29 Legal Studies 400.

${ }^{0}$ See, eg, Stevens (n 14) ch 8 (passim); Weinrib (n 9) 63-66; id, (n 81) 623; id, Corrective Justice (Oxford: OUP, 2012) 19; BC Zipursky, 'Civil Recourse and the Plurality of Wrongs: Why Torts are Different' [2014] New Zealand LR 145, 149154.

${ }^{91}$ For a defence of that what our judges say must be accorded proper respect in grand tort theories, even if what the judges say clashes with the core descriptive or explanatory claims of those theories, see Stapleton ( $\mathrm{n}$ 34). And as to (i) what it might mean to say that a tort is anomalous, and (ii) the problems associated with the various possible meanings of 'anomaly', see Murphy (n 15). 


\section{The Unlawful Means Tort}

The tort of causing loss by unlawful means assuredly contradicts the structural imperative. In $O B G$ $L t d v$ Allan $^{92}$ the House of Lords made clear that this tort requires the involvement of three parties, with the claimant's right of action being contingent upon the defendant committing a (potentially) actionable civil wrong against an intermediary. ${ }^{93}$ As we noted, a classic instance would entail D intimidating $\mathrm{X}$ into acting in a way that causes loss to C. ${ }^{94}$

Acknowledging the tort's non-bilateral structure, Stevens describes it as one of the recognised 'exceptions to the privity doctrine in the law of torts'.$^{95} \mathrm{He}$ then (as also noted) attempts to ameliorate the problem of fit that it poses for his theory by arguing that its existence can be justified because it 'prevents D from using others as a means to his own ends. ${ }^{96}$ But this is beside the point. The tort inescapably clashes with his foundational claim that, in tort, "persons who suffer loss because of the infringement of someone else's right do not have standing to sue'. ${ }^{97}$ Nor can his proffered justification, couched as it is in the language of deterrence, be reconciled with two claims he makes elsewhere in Torts and Rights. The first is that all policy considerations - which of course include the goal of deterrence - have no legitimate role to play in tort law; ${ }^{98}$ and the second being that, in any event, " $\mathrm{t}$ ] he evidence available for the deterrent impact of the law of torts is thin'. ${ }^{99}$ Taken together, these claims obstruct his would-be escape route. With one breath he attempts to justify this tort by reference to its deterrent effect. With the next he denies deterrence a legitimate role in tort.

Beever, too, essays an explanation of this 'aberrant' tort. Unlike Stevens, he dismisses from the outset the idea that it might be a justified departure from the structural imperative saying, 'there can be no justified exception to the privity rule'. ${ }^{100}$ He endeavours, instead, to show that, properly understood, it is not really an anomaly but, rather, a cause of action in respect of 'a violation of the plaintiff's innate right [to freedom from the control of others]'. ${ }^{101}$ The violation of this innate right, he maintains, occurs by virtue of the "coercion of the plaintiff by the defendant through another'. ${ }^{102}$ Thus, he concludes, the tort is orthodox in terms of its structure.

True, his explanation fits the relevant cases. Yet it has two major defects. First, it treats as an irrelevance the requirement that $\mathrm{D}$, to be liable, must have used unlawful means against a third party. 'Despite official doctrine', Beever writes, such 'unlawful means are not necessary ... [since] causing loss by unlawful means does not require unlawful means'. ${ }^{103}$ This is baffling. But it is not long before his true colours are revealed. Just a few pages later he asserts that D's attempt to exercise control over C 'ought to generate liability' ${ }^{104}$ in such cases. Notice the 'ought', here. For it exposes Beever's adoption of a nakedly prescriptive stance; an obvious departure from his endeavour to interpret the law as it presents itself. He is, in short, simply telling us what ought to be regarded as the gist of the tort in order for it to make sense.

The second snag centres on Beever's keenness to reconceptualise the action in accordance with the Kantian idea of an innate right to be free from the control of others. Here, the problem is that the reported cases make no mention at all of any such touchstone of liability. As Scott

\footnotetext{
92 [2008] 1 AC 1.

93 The qualification that there must have been a would-be actionable civil wrong committed against a third party was introduced into the definition of this tort by Lord Hoffmann: ibid, [49].

94 An example of such conduct might be $\mathrm{X}$ refusing to trade with $\mathrm{C}$.

${ }^{95}$ Stevens (n 14) 174

96 ibid, 188.

${ }^{97}$ ibid, 173.

${ }^{98}$ Stevens is adamant that '[j] udges should adjudicate on rights and leave issues of policy to be discussed by academics, and determined by the legislature': ibid, 311 .

99 ibid, 322-3.

100 Beever (n 4), 117.

101 ibid, 124.

102 ibid.

103 ibid, 135.

104 ibid, 137 (emphasis added).
} 
Hershovitz has rightly noted, it is true that 'judges sometimes grasp for principles they can't quite articulate. But for the most part, they are pretty good at saying what they mean, and the reasons they marshal in their opinions are in fact the grounds for their decisions'. ${ }^{105}$ That no judge has ever sought to anchor this tort to the putative right identified by Beever is extremely problematic for his avowed interpretive theory for the reasons that follow.

The idea of evincing an interpretive understanding of the law was most elaborately advocated by Ronald Dworkin. Yet Dworkin was careful to register an important caveat on how this may be done. Although, like Beever, he saw the general aim of the interpretive approach as being to identify 'which interpretation [of the case law] proposes the most value ... [ie] shows it in the better light, all things considered ${ }^{106}$ he was also insistent that ' $[t]$ he history or shape of an object constrains the available interpretations of it'. ${ }^{107}$ In other words, the interpretive approach can only be an exercise in trying to make sense of what we find before us. It does not stretch to fabricating what we would like to find. Thus, '[i]n order for moral reasons [like Kantian Right ${ }^{108}$ ] to be relevant to legal explanation ... they must be incorporated into the materials of the law in some way'. ${ }^{109}$

Beever seems to ignore not just this injunction but also his prior promise that 'the view advanced here [ie, in his theory] is found in the case law ${ }^{110}$ With the unlawful means tort, he seems content to ride rough-shod over the decided cases and to propose, instead, an alternative rationale for their outcomes. This is surprising given what he says about others who have suggested various rights (not actually articulated in the case law) in order to explain the tort of inducing breach of contract. In that connection he says: '[o]ne cannot account for the tort of inducing breach of contract merely by positing a right delineated so that it fits the contours of the action... it is necessary to reveal why precisely that right is recognised in law'. ${ }^{111}$ Yet that is exactly the manoeuvre he himself deploys in relation to the unlawful means tort. He relies on Kantian Right (never once mentioned by a judge) rather than on what was actually said by the courts in his attempt to explain this structurally aberrant cause of action.

Goldberg and Zipursky are more or less silent about the unlawful means tort. So, too, is Weinrib. But given that it represents a significant departure from the structural imperative to which they subscribe, their theories are also clearly wanting in this connection.

\section{Statutory Departures from the Structural Imperative}

The unlawful means tort is not alone in having a tripartite structure. Several other tort actions are similarly structured, including a number that have statutory foundations. The best known ones are the actions created by the fatal accidents, latent damage and congenital disabilities legislation. ${ }^{112}$ As noted already, Stevens acknowledges their existence, as well as the fact that they confer a right of action on $\mathrm{C}$ without there having been a breach of an ex-ante right held by $\mathrm{C}$ against $\mathrm{D}$. However, instead of admitting the significant problem of fit that these actions pose for his theory, he

\footnotetext{
105 Hershovitz (n 7) 969.

${ }^{106}$ R Dworkin, Law's Empire (Belknap Press, 1986) 53. Dworkin's approach is relevant since Beever signs up to Smith's conception of interpretive theory (Beever ( $\mathrm{n}$ 5); and Smith, in turn, acknowledges the consistency of his account with that of Dworkin: SA Smith, Contract Theory (OUP, 2004) 5.

107 ibid.

108 This entails the idea that A is entitled to behave as a free agent so long as his actions are compatible with an equal freedom in B. As Kant himself put it: '[a]ny action is lawful if it can coexist with everyone's freedom in accordance with a universal law': I Kant, The Metaphysics of Morals M Gregor Trans (CUP, 1996) 6:230.

109 WB Wendell, 'Explanation in Legal Scholarship: The Inferential Structure of Doctrinal Legal Analysis' (2010-11) 96 Cornell L Rev 1035, 1040.

110 Beever (n 4)124 (emphasis added).

111 ibid, 113.

112 Fatal Accidents Act 1976, s 1; Latent Damage Act 1986, s 3; Congenital Disabilities (Civil Liability) Act 1976, s $1(3)$.
} 
downplays their significance either on the basis that they are somehow anomalous, ${ }^{113}$ or (as noted earlier) because the result they produce is considered a palatable one. These manoeuvres fail, however, ${ }^{114}$ either because it is implausible that the 'exceptions' are anomalous, or because adverting outcomes that are somehow bearable is in no way a solution to the problem of fit that these actions create. However palatable the outcomes they produce may be, their incompatibility with his theory remains.

While Beever, Weinrib and Goldberg and Zipursky have nothing to say about these specifically English statutes, it is nonetheless evident that their theories are intended to explain tort law right across the common law world. ${ }^{115}$ Accordingly, it is significant that these actions clash equally as much with their theories.

\section{$3 \quad$ Passing Off and Injurious Falsehood}

Along with the unlawful means tort, most of the other economic torts depart from the structural imperative. ${ }^{116}$ Passing off and injurious falsehood are two good examples. In both torts, D's liability to $\mathrm{C}$ is contingent upon $\mathrm{D}$ having misrepresented something to a third party who consequently acts in a way that causes loss to C. Most of my target theorists are silent on the challenge posed by these torts. This leaves them with an explanatory deficit. The partial exception is Beever who, although he says nothing about passing off, does offer an account of injurious falsehood.

In his view, the tort is explicable in terms of a 'defendant [who] exerts control over the plaintiff via the mechanism of the party to whom the statement was made'. ${ }^{117}$ Superficially, this account appears to fit the relevant cases. But the explanation soon runs aground when juxtaposed with a central stipulation in Beever's theory. At a very early stage in $A$ Theory of Tort Liability, Beever makes clear his commitment to what he labels the 'principle of innocence'. ${ }^{118}$ This, he explains, is the idea that 'one is free to do anything that does not violate a right in another'. ${ }^{119}$ Why can't this be invoked in a malicious falsehood case where, typically, $\mathrm{C}$ will have lost custom after D's maliciously publishing an untruth about $\mathrm{C}$ to a third party who then shuns $\mathrm{C}$ 's goods. ${ }^{120}$ What right of C's is in play here? Beever does not spell this out. But, it is clear that in the absence of a rights violation, D should, on Beever's account, be able to rely on the innocence principle.

Perhaps he thinks it is the claimant's right to trade? After all, he claims elsewhere that 'the "right to trade" is an aspect of the innate right'. ${ }^{121}$ The trouble here is that no such right exists. We all have the liberty to trade, but no right, strictly speaking, to do so. No-one is under any (correlative) duty to buy our goods so the innocence principle would seem to be in play here. ${ }^{122}$ And so long as it is, Beever will remain unable to reconcile injurious falsehood with his theory.

\footnotetext{
113 This claim is made most forcefully in relation to the action created by the Latent Damage Act 1986, s 3 of which is described as 'an unfortunate anomaly': Stevens (n 14) 185.

${ }^{114}$ For detailed discussion of why such attempts to downplay the significance of these 'exceptions' in no way protect Stevens' general thesis, see Goudkamp and Murphy (n 54).

115 For the argument that they do purport to do this, see J Goudkamp and J Murphy, "The Failure of Universal Theories of Tort Law" (2015) 21 Legal Theory 47.

116 The economic torts are frequently structured in a way that confounds the structural imperative. For a brief sketch of the relevant torts and their tripartite structure, see J Murphy, 'Misleading Appearances in the Tort of Deceit' [2016] CLJ 301.

117 Beever (n 4) 171.

118 ibid, 20. It seems clear that he has in mind other rights than merely the innate right when he says that 'individuals commit wrongs - ie, act illegally - only if they violate the rights [plural] of others': ibid, 23.

119 ibid.

${ }^{120}$ Cases of what is called slander of goods - in which D disparages the quality of C's goods - are typical.

121 ibid, 125.

122 There may, of course, be an action for defamation available in some circumstances. But this is a different matter, involving a separate tort centred on C's reputational right. It leaves untouched the explanatory hurdle presented by injurious falsehood.
} 


\section{$4 \quad$ Vicarious Liability}

The vicarious liability principle (as it is generally understood) is another important deviation from the structural imperative. Recognising this, Stevens offers an alternative explanation of it: one that is consistent with his claims about the privity of torts. He contends that the term vicarious liability is a misnomer because it is the tortious acts of the employee (rather than his liability) which get attributed to the employer. ${ }^{123}$ In short, he prefers the old 'master's tort' understanding of vicarious liability. He admits that his preference for this understanding is rooted in its compatibility with the structural imperative. Conveniently, '[t]he attribution of X's acts to D means that D has infringed C's rights'. ${ }^{124}$

In order to shore up this interpretation, Stevens goes to great lengths to dismantle the various policy arguments that are typically invoked to support the rival, 'servant's tort' interpretation. He then concludes that none of these policy reasons, 'either individually or in combination provides a rationale for "vicarious liability" as we find it'. ${ }^{125} \mathrm{He}$ is right. ${ }^{126}$ But, for two reasons, his making this point is of no avail in terms of grounding his own interpretation.

First, we must recall Stevens' commitment to explaining the law 'as we find it'. This, crucially, is a very different enterprise from testing the rationales conventionally offered for the law as it presents itself. So even if he is correct that the various, commonly advanced policy justifications for the vicarious liability principle do not stack up, that is irrelevant in terms of his overall project. (In any event, it does not follow from the fact that others are wrong that he is right.) Secondly, it is important to note that the 'master's tort' explanation of vicarious liability - the one favoured by Stevens - has been explicitly rejected by our most senior judges. In the Majrowski case, Lord Nicholls said:

In times past this 'employer's tort' analysis of vicarious liability had respectable support in England. But since then your Lordships' House has firmly discarded this basis in favour of the 'employee's tort' approach... The employee's wrong is imputed to the employer... In this country this approach is now settled law. ${ }^{127}$

Stevens acknowledges the problem of fit presented by this case and accepts that the approach taken in Majrowsk $i$ is the orthodox one these days. Thus, faced with no way of reconciling the case with his theory, he simply invites the reader to accept that what was said there was uttered in error and that the decision 'is wrong'. ${ }^{128}$ Yet his invitation to disregard as wrong a case that bears all the hallmarks of orthodoxy is flatly inconsistent with his commitment to explain the law as it is found in the cases. It shores up his commitment to the structural imperative no more than his silence on malicious falsehood and passing off.

Since Weinrib also subscribes to a master's tort view of vicarious liability, ${ }^{129}$ he too is faced with the self-same problem of fit. Beever, by contrast, is non-committal on this question in Rediscovering the Law of Negligence. He suggests that an explanation of vicarious liability is not necessary in that book. He does, however, at one point, cite Weinrib as having offered a plausible explanation of vicarious liability. ${ }^{130}$ So, to the extent that he too subscribes to the master's tort interpretation, he is similarly unable to explain the law as it stands.

\footnotetext{
123 Stevens (n 14) 259-267.

124 ibid, 262 ..

125 ibid, 258.

${ }^{126}$ For the shortcomings of the putative compensation, loss-spreading, deterrence and enterprise-liability justifications for vicarious liability, see J Neyers, 'A Theory of Vicarious Liability' (2005) 43 Alberta LR 1, 5-15.

127 Majrowski v Guy's \& St Thomas' NHS Trust [2006] 3 WLR 125, [15] (emphasis added). Lords Hope and Brown agreed with Lord Nicholls (at [43] and [81] respectively), as did Baroness Hale ([68]).

${ }^{128}$ Stevens (n 14) 264. For what it might mean in this context to say that a decision is wrong, and the problems associated therewith, see Stapleton (n 34).

${ }^{129} \mathrm{He}$ opines that 'respondeat superior construes (indeed constructs) the doer as the composite: the-employer-actingthrough-the-employee': Weinrib (n 9) 196.

130 A Beever (n 5) 35.
} 
Goldberg and Zipursky appear to accept the servant's tort understanding of vicarious liability. They say that it 'presupposes the commission by an employee of an employment-relatedwrong and then expands the set of actors who can be held accountable for that wrong'. ${ }^{131}$ This being so, they must also accept its tripartite nature and thus the fact that it clashes with their equally unswerving commitment to the structural imperative.

\section{Remedial Heterogeneity}

Although it is not an argument explicitly made by any of the theorists with whom this article is principally concerned, this section considers the suggestion tort law's unity may be found in a primary remedy of reparative damages. The mere fact that this argument is not explicitly made in any of the theories in view does not mean that it can be ignored. This is because, although none of my target theorists claim explicitly that torts are unified by a reparative damages remedy, the belief that they are is implicit in what most of them they say. Weinrib treats the duty to repair as a central plank of tort law viewed as an instantiation of corrective justice. ${ }^{132}$ Stevens, although he uses the language of substitutive damages, also places such damages centre stage. ${ }^{133}$ And Beever does likewise. ${ }^{134}$

By contrast with these other authors, Goldberg and Zipursky do not regard remedial heterogeneity as problematic for their theory. Writing alone, Zipursky has even argued that 'our actual tort law ... does not give a central role to a duty of repair'. ${ }^{135}$ But, as we shall see, their being open to the possibility of remedies other than reparative damages does not mean that tort's remedial diversity is unproblematic for their theory.

If the argument (most forcefully advanced by Gardner) that torts can be united by reference to a primary remedy of reparative damages is sound, then my sub-thesis - that tort law's remedial heterogeneity belies the plausibility of the theories considered here - is vulnerable. To be clear from the outset on what he says, it is worth spelling out Gardner's claim that ' $t$ tort law cannot be understood without understanding the primacy of the reparative ${ }^{136}$ given that such damages are one of the 'defining features of the law of torts'. ${ }^{137}$ But is this true?

\section{Reparative Damages as a Source of Unity ${ }^{138}$}

In order to interrogate the idea that tort law may derive its unity from the primacy of reparative damages, it is useful to provide first a slightly fuller sketch of Gardner's thesis. He regards reparative damages as tort law's primary remedy inasmuch as they comprise 'the only remedy ...

\footnotetext{
131 JCP Goldberg and BC Zipursky, 'The Strict Liability in Fault and The Fault in Strict Liability' (2016) 85 Fordham LR 743, 755, n 50. Elsewhere, they declare it to be 'relationship-based ... rather than fault based': JCP Goldberg and BC Zipursky, Torts (OUP, 2010) 59.

${ }^{132}$ In a section of The Idea of Private Law dealing specifically with 'The Reparation of Tort Losses' he writes: '[w] hen the defendant ... breaches a duty correlative to the plaintiff's right, the plaintiff is entitled to reparation' (Weinrib (n 9) 135, emphasis added). At the same time, his hostility towards other remedies (such as punitive damages) is based on his absolute commitment to a 'bipolar conception of the [tort] remedy as the annulment of the parties' correlative gain and loss': ibid, 66.

${ }^{133} \mathrm{He}$ asserts that 'the granting of a specific remedy [eg, an injunction] is not properly characterized as a response to a tort' (Stevens (n 14) 57) and he describes the duty to pay damages - the true remedy available in tort - as being a 'duty of repair' (R Stevens, 'Rights Restricting Damages' in A Robertson and M Tilbury (eds), Divergencies in Private Law (Hart Publishing, 2014) 161.

134 'The goal of corrective justice is to undo the wrongdoer's wrong as far as it is possible to do': Beever (n 5) 45

135 BC Zipursky, 'Civil Recourse, Not Corrective Justice' (2003) 91 Geo LJ 695, 710.

136 Gardner (n 11) 61.

137 ibid.

138 Because the thesis belongs to him, I adopt here Gardner's term, 'reparative damages'. I nonetheless sympathise with the distinction between reparation and compensation made in Goldberg and Zipursky (n 132).
} 
[that] the successful plaintiff enjoys as of right ${ }^{139}$ By this he means that a court 'is legally bound to make a reparative award ... if one is sought'. ${ }^{140}$ Accordingly, regardless of what other remedies may be available for certain types of tort, it is because reparative damages are always available that he considers them a defining feature of tort law. Such damages, he goes on to argue, distinguish tort from other legal categories (especially contract and equity) in a way that Goldberg and Zipursky's broad claims about tort being a form of civil recourse (with no attempt to pinpoint a default remedy) does not. ${ }^{141}$

Though Gardner's arguments are powerful, they are also flawed in two key respects. First, they overlook the fact that there are some torts for which the only damages available cannot possibly be classed as reparative. Secondly, there are certain types of tort case in which no damages at all are available. Both types of case contradict his claim that reparative damages comprise a primary remedy in the sense in which he uses that term.

\section{(a) Cases where the only available damages are not reparative}

Some torts - including those in which D has made unauthorised use of C's chattels - allow for damages that are non-reparative. The awards made are frequently referred to as 'licence-fee' damages. These damages, like those in mesne profits cases, ${ }^{142}$ are calculated by reference to what the defendant has obtained rather than by reference to what the claimant has lost. Accordingly, any talk of reparation seems misplaced in such cases given that it takes great inventiveness to portray them as reparative. ${ }^{143}$ That said, two notable attempts to do this have been made. They warrant consideration.

According to Nicholas McBride, licence-fee damages should be understood as protecting 'the interest we have in being allowed to determine for ourselves how things go for us ... by compensating a claimant for the normative loss that he has suffered as a result of one of his libertyoriented rights being violated'. ${ }^{144}$ On this view, the damages repair an infringement of our right to decide how our chattels will be used. ${ }^{145}$ Kit Barker agrees that such damages are reparative in nature, but does not see things quite the same way. He thinks that McBride's account is too broad to capture accurately 'the law as it stands'. ${ }^{46}$ He suggests, instead, that:

a possible key to understanding awards of 'user', 'licence fee' and 'hypothetical bargain' damages (as they are variously called) may lie in identifying claimants ... as losing one or more legal powers associated with their primary claim-rights ... [in particular] a power to 'insist' on his claim rights, or to 'stop' their infringement by applying to a court for ex-ante injunctive relief. ${ }^{147}$

It is certainly true that a claimant's power to initiate legal proceedings in order to prevent the defendant from infringing certain of the former's rights has value. As Barker explains, that the 'power to insist on his primary rights and to stop an infringement through injunctive means has

\footnotetext{
${ }^{139}$ Gardner (n 11) 53.

140 ibid, 55.

141 As Gardner observes, 'civil recourse is a defining feature of private law as a whole' (ibid, 45); and the fact that torts 'are legal wrongs against particular people ... does not help to distinguish the law of torts from ... contract or from the law of equitable liability': ibid, 46.

${ }^{142}$ For examples of such cases, see J Edelman, Gain-Based Damages: Contract, Tort, Equity and Intellectual Property (Hart Publishing, 1999) 115.

143 Notably, Gardner seems to accept this when he observes that the courts have sometimes fabricated a means of presenting these gain-based damages as though they were reparative: Gardner (n 11) 56.

${ }^{144}$ NJ McBride, 'Restitution for Wrongs' in C Mitchell and W Swadling (eds), The Restatement Third: Restitution and Unjust Enrichment (Hart Publishing, 2013) 275.

145 Ripstein makes much the same argument to explain where the wrong in conversion lies: see Ripstein (n 7) 48

146 K Barker, 'Damages Without Loss: Can Hohfeld Help?' (2014) 34 OJLS 631, 640.

147 ibid, 633.
} 
monetary value is clearly evident in the way that ... [the claimant] can command a significant fee for relaxing any injunction actually obtained'. ${ }^{148}$ It is also true that Barker's explanation of such damages is capable of accounting for all the relevant tort cases in which licence-fee damages have thus far been awarded. But his account nonetheless comes up short. For there is a telling absence of licence-fee damages in other areas of tort law in which the facility to obtain a quia timet injunction plainly exists. Cases of misuse of private information, and certain cases of battery, are examples. ${ }^{149}$ The problem for Barker here is that the courts have never awarded licence-fee damages for these torts. If the loss of the power to obtain an injunction occurs, why are licence-fee damages never awarded in these cases? And why - if the loss of a chance to obtain an injunction were a true basis for reparative damages - would the courts have spelled out that, in the misuse of private information cases, the damages are designed to compensate 'an infringement of ... [the claimant's] right to privacy that cannot be justified'? ${ }^{150}$ As noted already, the courts generally say what they mean. So it is hard plausibly to attribute to them a different reason for their judgments than the ones they themselves supply. ${ }^{151}$

Put simply, Barker's interpretation of licence-fee damages is ultimately caught by the very same problem as McBride's: it has theoretical appeal, but lacks any solid support from the caselaw. Their explanations are certainly off limits for my target theorists given their shared commitment to explaining the law as it presents itself. McBride's and Barker's ingenious explanations cannot therefore be invoked by my target theorists to demonstrate the unity of tort along Gardnerian lines. And without any such unity the reductionist ambitions of their grand theories are thwarted. The more obvious conclusion - and the one offered here - is that, sometimes in tort, the only available damages are non-reparative. Cases in which only licence fee-damages are can be claimed are a prime example, for such awards are based squarely on the defendant's gain.

To understand why this is so, let's consider the classic example of D who, without permission, takes for a ride C's otherwise idle horse and brings it back well-fed, safe and fitter than before. ${ }^{152}$ Here, $\mathrm{C}$ can claim to have lost nothing. The damages he receives are assessed purely by reference to the gain made by $\mathrm{D}$, namely, the use value of the horse for the period it was taken. That the award is calibrated in this way patently clashes with corrective justice theories insofar as they insist upon the reparative nature of tort damages. ${ }^{153}$ In addition, licence-fee damages are no less mysterious for the rights theorist. According to Stevens, damages in tort law are 'substitutive' of the right infringed ${ }^{154}$ and are awarded as the 'next best thing' to the right itself. ${ }^{155}$ For Goldberg and Zipursky, '[t]ort law permits victims of relational, injury-inclusive wrongs to obtain a court's assistance in redressing the wrongs that have been done to them'. ${ }^{156}$ As against both theories, damages designed to make D account for the gain that he made (and which are computed accordingly) simply cannot be portrayed as substitute for C's right to possession of the horse, or in terms of an injury that $\mathrm{C}$ has suffered. ${ }^{157}$ Neither C's right, nor any injury suffered, plays any part in the calculus. ${ }^{158}$ The damages reflect only the use value of the horse enjoyed by $\mathrm{D}$.

\footnotetext{
148 ibid, 656.

149 This observation is McBride's; and he gives the battery example of D conducting a medical test on C without C's consent: see McBride (n 144) 275.

${ }^{150}$ Campbell v MGN Ltd [2004] 2 AC 457, [125] (Lord Hope).

${ }^{151}$ Hershovitz (n 7) 969.

152 Lord Shaw supplied this hypothetical example in Watson, Laidlaw \& Co Ltd v Pott, Cassels and Williamson (1914) 1 SLT 130, 139.

153 See Weinrib (n 9) passim.

154 Stevens (n 14) 79-84.

155 ibid, 60.

156 Goldberg and Zipursky (n 8) 946 (emphasis added).

157 Goldberg and Zipursky are adamant that '[a] tort is not simply a breach of a duty but a breach of a duty of noninjury': Goldberg and Zipursky (n 138) 367.

158 For further suggestions as to why Stevens' understanding of such damages as 'substitutive' may be called into question, see Barker (n 146) 644-5.
} 


\section{(b) Cases where damages are expressly forbidden}

Gardner's case for the primacy of reparative damages in tort also overlooks the fact that there are some cases in which no monetary award at all will be available. These clearly undermine the claim that reparative damages are available as of right. The clearest example is that of innocent breach of copyright. Under section 97 of the Copyright, Designs and Patents Act 1988 - an ostensibly obscure provision, but one which nonetheless features in a steady flow of reported cases ${ }^{159}-$ the prospect of obtaining damages is expressly excluded. The section states:

Where in an action for infringement of copyright it is shown that at the time of the infringement the defendant did not know, and had no reason to believe, that copyright subsisted in the work to which the action relates, the plaintiff is not entitled to damages against him, but without prejudice to any other remedy.

The fact that this section leaves open the prospect of some other kind of remedy, ${ }^{160}$ merely confirms that it is impossible to see reparative damages as tort's primary remedy in this context. A remedy that is expressly excluded cannot be a primary one.

\section{(c) Cases in which only quia timet injunctions are available}

A second class of case in which no damages at all are available is that in which the only available remedy is a quia timet injunction. Importantly, such injunctions are available in certain tort cases in which no right has yet been infringed, and in which no injustice requires correction. Such cases consequently clash with the theories in view. ${ }^{161}$

The obvious response for either rights or corrective justice theorists would be to say that actions in which these injunctions are sought prior to the actual commission of a wrong are not tort cases. But any such response is blocked by contradictory authority. In Torquay Hotel Co Ltd v Cousins, ${ }^{162}$ one question that arose was whether an action for a quia timet injunction against a trade union was barred by the tortious immunity granted to such bodies under section 4 of the Trade Union Act 1906. The claimant argued that, while actions for damages were undoubtedly barred (given that 'the intention of Parliament in passing the Act was to protect trade union funds' ${ }^{163}$ ), no such immunity existed in respect of actions for injunctive relief. More specifically, the claimant asserted that although the statute afforded immunity in tort, " $\mathrm{a}] \mathrm{n}$ injunction can be granted against a trade union because quia timet proceedings are not founded in tort [but in equity]'. ${ }^{164}$ Lord Denning MR flatly rejected that contention. He made clear that such actions were actions in tort to which the statutory immunity extended, saying:

Section 4(1) of the Trade Union Act, 1906, says that: 'An action against a trade union ... in respect of any tortious act alleged to have been committed shall not be entertained in any court.' ... That section clearly prohibits an action for damages. But does it prevent an action

${ }^{159}$ A Westlaw search revealed no fewer than 167 reported cases in which that section was considered.

160 For example, a court order for the delivery up to the claimant of an infringing copy of the relevant work under section 99 of the same Act.

161 Weinrib has defended previous accusations that, because injunctions are forward (not backward) looking his corrective justice based theory is unable to cope with injunctive relief generally. Using nuisance as an example, he argues that since 'the norms against nuisances instantiate corrective justice, then so do the injunctions that prevent nuisances': EJ Weinrib, Corrective Justice (OUP, 2012) 94. But there is an important limit built into his accommodation of injunctions here. It appears in his claim that 'corrective justice operates not only by requiring the defendant to repair a wrong, but also by granting the plaintiff an injunction that prevents the defendant from extending the wrong into the future' (ibid, 94-95, emphasis added). Crucial here is the notion of 'extending the wrong'. Cases in which quia timet injunctions are granted are ones in which no wrong can be extended, because no wrong has yet been committed.

162 [1969] Ch 106. The case was only overruled by OBG Ltd v Allan [2008] 1 AC 1 insofar as it recognised a tort of indirect interference with contract using unlawful means.

163 [1969] Ch 106, 130.

164 ibid. 
for an injunction? The words are a 'tortious act alleged to bave been committed ... It would be strange if a trade union could not be sued for the wrong [already] done before the writ, but could be sued for the self-same wrong to be done in the future. ${ }^{165}$

On this authority, then, actions for quia timet injunctions are regarded as actions in tort; and (importantly for present purposes) they are actions that are inexplicable from the perspective of both corrective justice and rights-based theories of tort including Goldberg and Zipursky's. ${ }^{166}$ Hershovitz summarizes the problem for the former thus: although '[c]orrective justice offers a neat explanation of compensatory damages, which may be fairly said to repair the loss a plaintiff suffered... tort sometimes grants injunctive relief that is prospective rather than corrective'. ${ }^{167}$ Those who accept Weinrib's view that corrective justice is concerned rectifying past wrongs ${ }^{168}$ plainly cannot explain a remedy that operates prospectively (at least not in the absence of some prior wrong $\left.{ }^{169}\right)$. For them, tort plays a purely responsive role: its operation is triggered only after a wrong has been committed. Essentially the same problem afflicts rights theorists who maintain that tort is about the secondary duties generated by the infringement of primary rights. ${ }^{170}$

That quia timet injunctions may be awarded in mandatory, as well as prohibitory, form, ${ }^{171}$ presents an additional explanatory problem for corrective justice theories inspired by Kant. This is because Kantian accounts cannot explain tort law insofar as it imposes affirmative duties to act for the benefit of another (essentially what would be required by a mandatory injunction). As Weinrib puts it: 'one person's need does not serve as the basis for obligating another to satisfy that need'. ${ }^{172}$ Under Kantian Right, there are no 'particular affirmative actions' we must fulfil, but instead a freedom 'to accomplish any purpose whatsoever, provided that the act is consistent [with an equal freedom in others]'. ${ }^{173}$

Ultimately, Gardner's contention that reparative damages are available 'as of right $t^{174}$ and can, as such, be considered a defining feature of tort law is unconvincing. The only way that the claim can be sustained is by adopting a Procrustian approach to the definition of tort law: one that severs from the corpus of this field cases in which only licence-fee damages can be obtained, and cases in which the only available remedy is a quia timet injunction.

\section{E. Conclusion}

Grand explanatory, reductionist theories of tort proceed from a misplaced belief in the juridical or structural unity of their subject. All of the theories considered here are unable (albeit to varying degrees) to account satisfactorily for tort law's heterogeneity. In particular - as this article

\footnotetext{
165 ibid, 140. Note also Zipursky's point that injunctive relief within tort law is rightly seen as part of tort law rather than a legal graft onto tort law because, when a court grants such an injunction, 'it is doing so because of the parties' rights under tort law’: see BC Zipursky, 'Civil Recourse, Not Corrective Justice’ (2003) 91 Georgetown LJ 695, 713.

166 Goldberg and Zipursky make the standing requirement central to their Civil Recourse theory (Zipusrky (n 165) 714-8). In turn, this standing requirement hinges on the commission of a wrong which, in their view requires the breach of a legal duty owed by the defendant to the claimant (Goldberg and Zipursky (n 8) 951).

167 S Hershovitz, 'Corrective Justice for Civil Recourse Theorists' (2011) 39 Florida State Univ L Rev 107, 108.

168 Weinrib (n 9) 135: 'tort law places the defendant under the obligation to restore the plaintiff, so far as possible, to the position the plaintiff would have been in had the wrong not been committed'.

169 Above (n 161).

170 Stevens (n 14) 2. Goldberg and Zipursky, as noted above, prefer to express the same point in terms of civil recourse for wrongs.

${ }^{171}$ See, eg, Hooper $v$ Rogers [1975] Ch 43.

172 Weinrib (n 9) 97. Ripstein, too, believes that 'the law of torts never requires you to use your means in a way that is best suited to another person's use of his or her own means': Ripstein (n 7) 62.

173 ibid. Beever is equally unable to explain such injunctions as he, also, is committed to such thinking about affirmative duties: see Beever (n 5) 222.

174 Gardner (n 11) 53.
} 
demonstrates - three key aspects of tort's heterogeneity prove problematic for them: the fact that there is no universal form of liability which unites this diverse 'family' of wrongs, ${ }^{175}$ the fact that there are multiple departures from the structural imperative to which the theorists in view all subscribe, and the fact that torts cannot derive unity from a putatively as-of-right remedy in the form of reparative damages.

Insofar as my target theorists all offer reductionist theories of tort law - theories that proclaim the existence of some or other unifying feature (whether it be juridical, structural or remedial in nature ${ }^{176}$ ) - they all fail to fulfil their ambition. And though I do not say that any such theory of tort law is impossible; I would nonetheless suggest that one that is truly attentive to the law as we find it seems highly improbable.

175 We saw that torts of strict liability pose an especial problem for Weinrib's theory because they are relatively commonplace, yet by his own admission, incompatible with his theory. We saw, too, that one particular example of strict liability - the rule in Rylands v Fletcher (or at least its American counterpart) - is incomprehensible according to the rights theories propounded by Stevens, and Goldberg and Zipursky. Its challenge, from their perspective, inheres in the fact that it represents an instance of tortious liability in the absence of a rights infringement. And just as Weinrib was ensnared by the fact that numerous examples of strict liability could be cited, so too were the rights theorists faced with a fair number of other examples of tortious liability in the absence of rights violations.

176 The use of the word 'or' is important since rights theorists do not sign up to the juridical claims about tort law made by corrective justice theorists of the Weinribian persuasion. Indeed, Stevens expressly distances himself from the notion that tort - in contrast to breach of contract and equitable wrongs - can claim what he calls 'conceptual unity': Stevens (n 14) 286. However, he is firmly committed to the structural imperative; and that he attaches very great significance to this structural unity, is clear from what was argued in section C. 